\title{
'N ONWAARSKYNLIKE VOORSTEL VIR 'N ONGELOOFLIKE SPEL
}

\author{
Lt J.E. Holloway*
}

A parallel is drawn between the game of chess and the 'game' of war and the use of credit cards in the civilian world and that of credits obtained or lost in the world of the soldier. Certain similarities are pointed out as well as a number of differences. Suggestions are put forth to improve the players' game and whereas (as the author points out) his suggestions are rather unlikely as far as the 'game' of war and soldiering are concerned, it is nevertheless unbelievably realistic and so gripping that you find yourself wondering: is it really so far-fetched an idea?

Geagte Opper-offisiere, Offisiere, Onder-offisiere. Here van die Patentekantoor, en - laaste maar nie die minste - Entrepreneurs: ek het my in die afgelope ses maande, die eerstes van my Nationale Diensplig, dikwels verstom oor hoe ver verwyderd die moderne lewenswyse van die militêre werkswyse is, en hoe groot die aanpassing is wat die Nuwe Rekruut moet maak. Soos elke Opvoeder weet, is spel een van die mees waardevolle hulpmiddels tot sy beskikking en, denkend hieraan, het ek onlangs begin om ' $n$ Spel te formuleer wat hierdie aanpassing kan vergemaklik.

Die gebruik daarvan is egter nie hiertoe beperk nie: onder-offisiere sal dit met vrug kan gebruik, nie net ter opknapping van hulle eie kennis nie, maar ook as herinnering aan die feit dat hulle ook eens met dieselfde probleme moes worstel. Dit sal hulle dus help om selfs onder die mees veeleisende omstandighede ' $n$ mate van perspektief en simpatie te behou. Dit is ook ' $n$ spel wat groot kommersiële waarde inhou en sal ' $n$ ideale Kersof verjaardagpresent wees; entrepreneurs sal die waarde van hierdie mark besef.

Maar my verbeelding reik nog verder. Volgens legende is skaak die geesteskind van 'n wyse man aan die hof van 'n Oosterse koning wie se naam in die vergetelheid van die tyd verlore geraak het. Dié koning was 'n dapper soldaat, 'n uitstekende strateeg en gedurig besig om sy mag uit te brei. Maar een oggend het die koning wakker geword, oor sy ryk uitgekyk en besef dat hy die hele bekende wêreld verower en onderwerp het. Daar was geen verdere veldslae om te wen nie, geen nuwe oorwinnings om te getuig van sy mag nie. Hy het rusteloos en knorrig geword. Dit was tóé dat die wyse man skaak ontwikkel het en aan sy koning voorgelê het. 'My Heer,' het hy gesê, 'op hierdie bord kan u oorloë voer, strategieë beplan en volkere onderwerp sonder om bloed te stort en u skatkiste leeg te maak.' Die koning was so ingenome met die spel dat hy nooit weer nodig gehad het om oorlog te voer nie.

Hoe amper kon skaak nie oorlog vervang het nie! Met elke geskil kon die opponerende konings dan bymekaar kom en op die skaakbord hulle magte teen mekaar opstel en so hulle militêre kragte meet. Helaas! Dit het nie toe gebeur nie en dit sal nog minder nou gebeur. En die rede is eenvoudig: skaak is ' $n$ spel van wiskundige presiesheid, van onvermydelike oorsaak en gevolg. Dit word nie met dobbelsteentjies gespeel nie Maar met etlike wysigings kan ' $n$ 'hoër' vorm van my spel ook bemark word, een waarin al die logistieke probleme, interne struweling, skietstakings en kompromievoorstelle, en alle ander X'e, Y's en Z's wat die moderne oorlogkunde kenmerk, ook betrek word. En net soos jong rekrute dan bymekaar sal kom om die spel te speel en te leer wat oorlog en soldaat-wees behels, kan staatsmanne en/of rewolusionêre leiers bymekaar kom om hulle geskille sonder bloedvergieting by te lê. (Ek erken een probleem: dit sal dalk nodig wees om 'n rewolwer teen die rewolusionêre leiers se koppe te hou om te verseker dat hulle volgens die reëls speel. En dit sal groot integriteit verg om dit nie te gebruik indien lg. die spel tog wen nie.)

Maar genoeg dagdrome - 'n burgerlike gewoonte wat na ses maande in die weermag nog nie totaal deur my afgeskud is nie. En voort met die spel. Toegegee, die spel vertoon enkele vae ooreenkomste met skaak, maar dit staan in die werklikheid veel nader aan dáárdie spel wat die kapitalisme in al sy opwinding, maar ook sy hebsug uitbeeld, en wat ongelukkig slegs onder ' $n$ geregistreerde handelsnaam bekend staan. 'n Verdere wenk: dit beeld heel toepaslik die hoofstad van die grootste handelsryk van alle tye op 
die speelbord uit, en dit is hier waar die spelers in materiële stryd gewikkel gaan wat enige militêre stryd in wreedheid oorskadu.

In my spel word die beboubare persele egter vervang deur verskeie opleidingsfases wat 'geslaag' word, eerder as 'gekoop' word. Die wenner is die eerste persoon wat alle opleidingsfases slaag. Aangesien soveel eksterne faktore gedurig op die rekruut se lewe inwerk, word die stasies en publieke dienste vervang met - kom ons noem hulle geleentheidsblokke, waarvan daar dus meer as twee keer soveel is as in die spel wat ons almal in ons agterkoppe het. Daar word nie met geld gespeel nie (die rekruut mag nog nie bier koop nie), maar wel met kredietkaarte. Die reëls sal dit aan die rekruut baie duidelik moet stel dat hierdie nie die wonder van die moderne bankwese is waarmee hy ná sy diensplig sal te doen kry nie; net soos vir geld, moet hy werk en nogmaals werk vir hierdie tipe krediet. Geleentheidskaarte in die spel sal dit by hom tuisbring dat die goeie soldaat tydens sy basiese opleiding nagte lank met twee uur slaap tevrede is, solank hy 'n krediet kan verwerf. Die kredietkaarte word dan gebruik om opleidingsfases te 'koop', negatiewe geleentheidskaarte teen te werk en met die HK te onderhandel. (Die HK het 'n soortgelyke funksie as die bank in 'daardie ander spel', en die ooreenkoms is duidelik: geld is mag/rang is mag.) Verskeie ander aspekte kan feitlik sonder verandering in my spel opgeneem word: die beginpunt word met ' $n$ betaalparade vervang, vry parkering met 'n pas, en die tronk met DB. (Natuurlik gepaardgaande met 'n aansienlike verlies van krediete.)

Die spel sal dus soos volg werk: een van die spelers sal beheer oor die HK hê en aan elke speler 'n klein aantal kredietkaarte uitdeel, sodat die stryd teen die HK en die slaag van die fases nie totaal onmoontlik voorkom nie. Daarna sal elke speler sy weg om die speelbord begin baan deur die dobbelsteentjies te rol. Land hy op 'n faseblok, kan hy deur ' $n$ aantal kredietkaarte aan die HK te oorhandig begin om die fase onder die knie te kry. Land hy op 'n geleentheidsblok, tel hy 'n geleentheidskaart op. Dit is dan veral hier waar die jong rekruut die geleentheid het om die militêre werkswyse in al sy glorie te leer ken. Daar hoort minstens 200 geleentheidskaarte te wees, en 'n mens kan selfs 'n aantal totaal verskillende stelle hê, sodat die rekruut die spel etlike kere kan speel sonder om dieselfde kaart twee keer raak te loop.

Ter illustrasie volg 'n lys van moontlike geleent- heidskaartlesings. Die leser kan sy verbeelding gebruik om die lys uit te brei en, indien my voorstel ernstig opgeneem word, kan 'n Kommissie van Ondersoek selfs aangestel word om 'n volledige lys op te stel om so die entrepreneurs te help verhoed dat die spel in 'n blote kommersiële truuk verval.

1. Berei voor vir Bevelvoerdersinspeksie: mis volgende twee beurte.

2. Haal eerstespan rugby: verkry twee krediete.

3. Afwesig tydens appél: verloor een krediet.

4. Onverwagte lakenruilparade: gaan terug na waar jy die beurt begin het.

5. Kry naweekpas: gaan voort na betaalparade.

6. Sukkel met dril: bly hier staan totdat 'n dubbel gegooi word.

7. Kom eerste in 2,4 km: speel weer.

8. Verslaap: verloor twee krediete.

9. Afwesig sonder verlof: gaan direk DB toe.

10. Druip vorderingstoets: handig nuutste fasekaart aan HK terug.

11. Rapporteer siek en gaan op ligte diens: beweeg volgende twee beurte slegs helfte van wat dobbelstene aandui.

12. Haaks met korporaal: verloor een krediet.

13. Swak inspeksie: verloor twee krediete.

14. Swak salueer en eerbewys: verloor twee krediete.

15. Ontvang pakkie met biltong van die huis af: ruil vir een krediet.

Die moontlikhede is eindeloos. Sou die spel byval vind, kan mens werk aan verdere verfynings en spesialisasie: 'n spel vir die Lugmag, of die Infanterie, of die PDK; mens kan selfs 'n spel ontwikkel vir die meer gevorderde dienspligtige, wat dan meer positiewe en negatiewe geleentheidskaarte sal bevat. En dan bly die uiteindelike doelwit steeds die spel vir staatsmanne...

Ek self soek geen roem of finansiële voordeel hieruit nie; die roem kom my instrukteurs toe, wat my so deeglik onderrig het in die valkuile van die militêre werkswyse. Alle finansiële voordele bemaak ek hiermee aan die Suiderkruisfonds, selfs al besef ek dat die dubbele rol van verspreider en dividendtrekker moontlik tot 'n Monopolie kan lei. Slegs as my idee van 'n spel vir staatsmanne tot rypheid kom sal ek 'n standbeeld as nie onvanpas aanvaar, en dan sal ek verkies om te perd uitgebeeld te word, en voor die geboue van die VVO te staan.

* Met hierdie bydrae het Lt Holloway die 2de Prys verwerf in die Militêre Opstelwedstryd van 1982. 